pp. 796-806

\title{
Transformation of Public Finance of the Eurasian Economic Union Member States in the Context of the COVID-19 Pandemic
}

\author{
Submitted 06/06/20, $1^{\text {st }}$ revision 16/07/20, $2^{\text {nd }}$ revision 26/08/20, accepted 15/09/20 \\ N.G. Vovchenko ${ }^{1}$, O.B. Ivanova ${ }^{2}$, A.F. Khapilin ${ }^{3}$, S.A. Khapilin ${ }^{4}$, \\ E.D. Kostoglodova ${ }^{5}$, A.I. Borlakova ${ }^{6}$
}

Abstract:

Purpose: The article sets the following objectives: considering the economic nature of the current crisis, its differences from the economic crises observed in the past few decades, the measures taken by the member states of the Eurasian Economic Union to fight coronavirus infection and the directions for improving financial, budgetary, tax , customs regulation in crisis conditions.

Design/Methodology/Approach: Right after the start of the coronavirus pandemic, most countries of the world have implemented a similar set of measures to minimize its negative consequences. The article examines the financial and credit instruments used in world practice to stabilize the socio-economic situation and eliminate the consequences of the COVID-19 pandemic, the possibilities and limitations of their use by the Eurasian Economic Union (EAEU) member states.

Findings: Overcoming the consequences of the economic crisis caused by the coronavirus pandemic and ensuring the economic growth of the EAEU member states is possible through the deepening of integration processes within the EAEU and the Shanghai Cooperation Organization ( $S C O$ ), the creation of the necessary conditions for the digitalization of foreign and mutual trade of the EAEU member states, changes in the current monetary policy its close coordination within the framework of resolving the issue of developing the internal financial market of the EAEU.

Practical Implications: The practical implementation of the proposed approaches will minimize the negative consequences of the economic crisis caused by the COVID-19 pandemic for the EEU member states.

${ }^{l}$ DSc., Professor, Department of finance, Rostov State University of Economics, Rostov-onDon, Russian Federation, nat.vovchenko@gmail.com;

${ }^{2}$ DSc., Professor, Department of finance, Rostov State University of Economics, Rostov-onDon, Russian Federation, sovet2-1@ rsue.ru;

${ }^{3}$ Candidate of Geological and Mineralogical Sciences, Department of International Trade and Customs, Rostov State University of Economics, Rostov-on-Don, Russian Federation, khapilin@mail.ru;

${ }^{4}$ DSc., Professor, Department of International Trade and Customs, Rostov State University of Economics, Rostov-on-Don, Russian Federation, khapilin-sa@mail.ru;

${ }^{5}$ Ph.D., Associate Professor, Department of finance, Rostov State University of Economics, Rostov-on-Don, Russian Federation, ramachka2006@ rambler.ru;

${ }^{6}$ Postgraduate student, Institute of Economics and Management, Department for Finance and Credit, North Caucasus Federal University, amibor00@mail.ru; 
Originality/Value: The rapidly changing macroeconomic and financial situation has a negative impact on the state of public finances around the world, which requires taking newly emerging fiscal risks into account and developing economic and financial measures to eliminate the consequences of the COVID-19 pandemic. Coronavirus infection has led to a disruption in the activity of certain sectors of the economy, a decrease in the final demand for manufactured products and / or services, a disruption of inter-industry relationships and production chains.

Keywords: Eurasian Economic Union (EAEU), public finance, COVID-19 pandemic, financial leverage.

JEL codes: G 28, G38, F02, F15.

Paper type: Research article.

\section{Introduction}

The COVID-19 pandemic turned to be a major economic shock for most countries in the world. Despite the fact that initially the crisis was caused by epidemiological problems, its development has an important financial and economic aspect, since the measures introduced to fight the virus carry extremely high economic costs, which is associated with a drop in production, incomes of the population, and a decrease in investment due to increased uncertainty (Grima et al., 2020: Khan et al., 2020).

For Russia, over the past decades, economic crises have had different economic and territorial projections. If the financial crisis of 1998 brought down many banks and the ruble exchange rate, mainly affected the the regions where dollar settlements were most common (especially Moscow), then the crisis of 2008-2009 was already industrial in nature, touched upon the metallurgical and machine-building regions, where the deepest industrial decline was observed. The regions of oil production and the Far East suffered less. Crisis at the end of 2014-2016 already had other "pain points" and its consequences are associated with a sharp decline in investment, mainly in industrial regions, consumption, a decline in household income, an increase in regional budget deficits, etc. (Zubarevich, 2020).

One of the most important features of the current economic crisis is the extremely uneven distribution of economic costs associated with measures to slow down the spread of the virus. In the context of industries, the transport, the tourism industry, and the service sector (ones requiring physical interaction with customers (restaurants, hairdressing salons, etc.)) primarily suffered from the measures introduced. In other words, the current crisis has hit the market services sector hardest of all, which is concentrated mainly in large cities with a population of one million and large regional centers, where the inevitable consequence will be an increase in unemployment, 
which did not happen in past crises. Territorial risks have grown significantly, as regional budgets faced an unprecedented decline in tax revenues.

The measures taken in foreign countries and in Russia, fiscal and credit measures to support the population, regions and small businesses, imply a new understanding of theoretical and methodological approaches to the implementation of fiscal and monetary instruments in the context of the coronavirus pandemic.

\section{Theoretical Foundation and Research Focus}

Currently, there is a wide range of opinions in the economic works regarding the nature and economic costs of the current crisis, its differences from the economic crises observed in the past few decades. Nevertheless, it is a situation of high uncertainty that a structured theoretical and methodological substantiation of possible scenarios for the development of events and the consequences of various measures taken becomes especially relevant. Research shows that the spread rate of infectious diseases accelerates during periods of economic growth, which is associated with higher economic activity, increased interregional mobility, domestic and international tourism (Adda, 2016).

After the outbreak of the COVID-19 pandemic, studies appeared combining both epidemiological and economic components, analyzing the impact of both the virus itself and the measures taken by the state to hold it. These studies have demonstrated both the effectiveness of introducing stringent quarantine measures (Thunstrom et al., 2020) and the cost-effectiveness of more targeted approaches to combating the virus than introducing general restrictive measures such as mass virus testing, tracing the contacts of virus-positive people etc., (Berger et al., 2020).

Today, it is possible to identify several potential theoretical and methodological issues requiring reflection and a fundamental decision at the end of the crisis phase. First of all, the question of the role of the state in the economy will become acute. During a crisis, the role of the state sharply increases and, at the same time, it does not always return to its original level after its end.

The lessons of past economic stresses for public finances indicate the need for an objective assessment of a wide range of potential budgetary risks in order to comprehensively identify them and make preventive management decisions. In this context, an important role is assigned to measures ensuring the transparency in disclosing budgetary risks, identifying possible consequences by determining the connections between the grounds for taking measures and the costs of their implementation. At the same time, in modern conditions of increased uncertainty, it is almost impossible to determine the duration of the economic impact of the Covid- 
19 outbreak on the state of public finances and to fully assess the materialization of budgetary risks (Balibek et al., 2020).

The issue of the role of economic unions and their supranational bodies in solving the issues of fighting epidemics and leveling its negative economic consequences requires at individual consideration, since most economic unions are based on a customs unions, which provides for the establishment of uniform rules for crossing the customs border by goods, vehicles and individuals within a single customs territory, as well as the application of united measures of customs-tariff and non-tariff regulation, in particular, in relation to goods necessary to combat the epidemic and eliminate its consequences. This is a crucial issue for Russia and other EAEU member states, since the effectiveness of measures to eliminate the consequences of the epidemic taken at the supranational level largely determines the expansion of the competence of the Eurasian Economic Commission and the prospects for Eurasian economic integration as a whole.

\section{Results}

After the start of the coronavirus pandemic, most countries of the world have implemented a similar set of measures to minimize its negative consequences (Table 1). Swift action was taken to strengthen the health system to control the infection and limit its spread. As a priority measure to curb the spread of COVID-19, countries with varying degrees of radicalism have implemented measures to isolate regions with outbreaks of the virus: from restrictions on international movements, suspension of public institutions and public transport to complete closure of transport links, introduction of an emergency regime.

Table 1. System-wide measures taken by states to minimize the consequences of the coronavirus pandemic

\begin{tabular}{|c|c|c|}
\hline $\begin{array}{l}\text { Optimization of movement of } \\
\text { goods and individuals across } \\
\text { the customs border }\end{array}$ & Economic support measures & Population support measures \\
\hline $\begin{array}{l}\text { Introduction of simplified } \\
\text { procedure for the import of } \\
\text { essential and medical goods }\end{array}$ & $\begin{array}{lll}\text { Direct financial support for } \\
\text { strategic entities }\end{array}$ & $\begin{array}{l}\text { Increase in the production of } \\
\text { medicines, creation of antiviral } \\
\text { drugs and vaccines }\end{array}$ \\
\hline $\begin{array}{l}\text { Simplifying the procedure for } \\
\text { obtaining permits for goods } \\
\text { necessary to fight the } \\
\text { consequences of COVID-19 }\end{array}$ & $\begin{array}{l}\text { Preferential loans for } \\
\text { replenishment of working capital } \\
\text { of SMEs, credit holidays, } \\
\text { refinancing of loans }\end{array}$ & $\begin{array}{l}\text { Targeted social support for } \\
\text { socially vulnerable segments of } \\
\text { the population, people who have } \\
\text { lost income }\end{array}$ \\
\hline $\begin{array}{l}\text { Establishment of round-the- } \\
\text { clock operation of individual } \\
\text { customs border checkpoints }\end{array}$ & $\begin{array}{l}\text { Monitoring and prompt adoption } \\
\text { of measures to prevent unjustified } \\
\text { price increases due to volatility of } \\
\text { exchange rates of national } \\
\text { currencies }\end{array}$ & $\begin{array}{l}\text { Development of programs for } \\
\text { anti-epidemiological support of } \\
\text { the population, taking into } \\
\text { account the experience of the } \\
\text { pandemic }\end{array}$ \\
\hline $\begin{array}{l}\text { Exemption from } \\
\text { customs duties on }\end{array}$ & $\begin{array}{l}\text { Cuts in key interest rates by } \\
\text { central (national) banks }\end{array}$ & $\begin{array}{l}\text { Restriction of holding mass } \\
\text { events, reduction of foreign }\end{array}$ \\
\hline
\end{tabular}




\begin{tabular}{|l|l|l|}
\hline $\begin{array}{l}\text { necessary to fight the } \\
\text { consequences of COVID-19 }\end{array}$ & $\begin{array}{l}\text { travel, reduction of working } \\
\text { hours }\end{array}$ \\
\hline $\begin{array}{l}\text { Introduction of a temporary ban } \\
\text { on the import of certain } \\
\text { medicals }\end{array}$ & $\begin{array}{l}\text { Suspensium of verification } \\
\text { activities, initiation of bankruptcy } \\
\text { proceedings }\end{array}$ & $\begin{array}{l}\text { Comprehensive support for } \\
\text { healthcare professionals }\end{array}$ \\
\hline
\end{tabular}

Source: Own elaboration.

In Russia, the spread of the pandemic has put a dilemma on the agenda: either to finance the shortfall in non-oil and gas revenues primarily through borrowing under the current fiscal rule, or to actively use the National Wealth Fund (NWF), deviating from the budget rule?

For Russia, as well as for some other countries, amid the coronavirus pandemic with a drop in both oil and gas and non-oil and gas revenues, there is an acute problem of modifying the current fiscal rule in order to ensure its greater long-term sustainability and flexibility. To this end, the introduction of a "contingency clause" into it on the basis of a fairly strict algorithm for making this decision and determining the sources of financing for shortfalls in oil and gas revenues will contribute to the softening of the budget rule.

Two fundamentally different models of stabilization of the socio-economic situation could be distinguished - "eastern" and "western" ones. The features of the "eastern" model are the implementation of large projects, support for export-oriented industries, the "western" model includes the expansion of funding for existing programs, both government (health programs, support for socially vulnerable groups of the population, development of SMEs) and central banks (buyback programs) (Noja and Cristea, 2018).

In the face of a worsening economic situation in most of the EAEU member states, measures are introduced to stabilize the economy, mainly according to the "western" model. In response to the causes of the crisis, measures of budget support were deployed, as well as monetary policy measures aimed at countering the spread of infection and stabilizing the economic situation.

State programs to support the population and business, developed by the governments of the EAEU member states are similar in their focus. In Russia and Kazakhstan, the need to develop post-crisis recovery programs is boosted, among other things, by the decline in world oil prices and the persistence of high uncertainty about the prospects for their recovery, which required the formation of new sources of economic growth. In all EAEU countries, except for Kyrgyzstan, industries that require additional measures of budgetary support were identified - mainly manufacturing, trade and public catering, tourism, and transport. Additional budgetary funds were allocated: in Armenia - to agriculture; in Belarus - the aviation industry, real estate operations, education and healthcare; in Russia - to the air transportation industry, the construction complex, the culture and sports, retail trade in non-food products; in 
Kazakhstan - to construction, energy, real estate ones. In Kazakhstan and Russia, an additional list of systemically important enterprises has been formed to provide targeted assistance from the state.

As part of supporting economic activity and business in all EAEU countries, the following general areas of budgetary and financial support for businesses and the population could be identified:

1. System-wide measures. A suspension of bankruptcy, tax inspections, customs and other regulatory authorities was introduced. The validity of all previously issued licenses, certificates and other permits related to the conduct of entrepreneurial and certain types of activities has been extended. The governments of a number of EAEU countries have established a temporary postponement or introduced a moratorium on the payment of payments for renting state or municipal property. The requirements for securing government contracts have been reduced, and penalties for small and medium-sized businesses have been canceled. A free regime has been established for the issuance of state certificates of force majeure circumstances by authorized bodies in accordance with the terms of foreign trade transactions and international treaties.

2. Tax incentives. The governments of the EAEU member states provided deferrals for the payment of a number of taxes and mandatory payments, reduced the rates of mandatory social payments - mainly for small and medium-sized businesses, imposed a suspension of the accrual of fines and penalties, as well as compulsory collection from taxpayers of debts on taxes and social payments.

3. Concessional financing from budget funds. Non-repayable budgetary funding was provided to organizations most affected by the pandemic. All sectors of the economy have the opportunity to obtain loans on preferential terms, as well as interest-free loans to pay wages, state guarantees for small and medium-sized businesses in the absence of the necessary collateral for obtaining loans, partial subsidizing of interest on loans and deferral of loans already issued.

4. Measures of monetary regulation. The central banks of the EAEU member states took measures to support the economy by lowering rates, reducing regulatory requirements. In order to mitigate the negative consequences of the pandemic and stimulate economic growth, the central banks of Armenia, Kazakhstan and Russia reduced interest rates and refinancing rates: in Armenia by 0.25 percentage points to $5.25 \%$, in Kazakhstan the base rate was reduced to $9.5 \%$, in Russia the key rate was reduced by 0.5 percentage points 
to the level of 5.5\%. In Belarus, the rate was changed before the start of the pandemic and amounted to $8.75 \%$. At the same time, the central banks of a number of EAEU countries adopted programs of concessional lending and refinancing loans to small and medium-sized businesses.

5. Support of the population. The governments of the EAEU countries are implementing a number of key state programs to mitigate the social consequences for the population caused by the pandemic - in particular, providing financial aid to those who lost income during the pandemic, providing one-time benefits to families with children and pregnant women, providing food packages to socially vulnerable segments of the population, financial support for medical workers involved in the fight against coronavirus infection, subsidies or postponement of payments to the population for utility bills.

6. Measures of customs regulation of foreign economic activity. In the context of the transfer of powers in the field of customs regulation of foreign economic activity, measures related to the organization of the work of customs authorities during a pandemic, the implementation of foreign economic policy measures, customs tariff and non-tariff regulation were carried out at the supranational level by the Eurasian Economic Commission.

At the initial stage of the pandemic, the Eurasian Economic Commission ensured the creation in the member states of the Union of a "green corridor" for the import of critical goods necessary to prevent and eliminate the consequences of the coronavirus pandemic, temporarily introduced a tariff benefit in the form of a complete exemption from payment of import customs duties until June 30, 2020 for a number of agricultural and food products, as well as selected finished pharmaceuticals and medical products. Also, the procedure for granting the "A" country of origin certificates issued in order to obtain tariff preferences for trade in developing and least developed countries has also been temporarily simplified - until September 30, 2020, it is allowed to use a paper or electronic copy of certificates for customs declaration.

As part of the "second package" of measures, by the decisions of the EEC Board, a temporary suspension was established on the export of a number of food products, personal protective equipment, disinfectants, medical products and materials from the EAEU member states. The EAEU governments are entrusted with the provision of mutual assistance, including the provision of humanitarian assistance, an increase in the supply of goods on a commercial basis in the conditions of a shortage. An extraordinary procedure for discussion and a reduction to 10 days after the publication on the EEC website of the introduction of decisions related to measures responding to the spread of coronavirus infection (in the areas of customs tariff, non-tariff and 
customs regulation, transport, sanitary, veterinary, quarantine phytosanitary control, technical regulation and labor migration).

Despite the temporary and medium-term nature, the decisions taken help to stabilize the economic situation in the EAEU are of great importance for the population of the Union countries, provide conditions for recovery and ensure the further development of economies. The effectiveness of measures taken at the state and intergovernmental level to support the economy could differ significantly depending on the scenarios for the development of the epidemiological situation.

The issue of developing flexible mechanisms of budgetary support for the population (targeted social assistance, unconditional basic payments to the population or to certain categories of citizens) is being actualized. To support the real and banking sectors, measures to ensure liquidity, concessional financing, reduce administrative costs, and a suspension of verification activities by regulatory authorities will remain relevant. At the same time, the relevance of the measures taken in the first half of 2020 regarding the development of systemic protection measures, the development of investment, scientific and technological programs in the field of biotechnology and protection of the population, on the contrary, will significantly increase.

In general, the budgetary resources of the EAEU countries (with the exception of Russia and Kazakhstan) are limited for large-scale anti-crisis stimulation measures for the economies: the 2009 crisis caused the annual (except for the last two years) debt of the general government sector of most EAEU member states. In Kazakhstan and Russia, this indicator is relatively low. However, in all EAEU countries it is significant, varying from 7 to 35 percentage points higher than in 2008. In the current environment, Russia and Kazakhstan have significant raw and fiscal reserves that can be used to promote the economic growth if the epidemiological background worsens, the need to prolong quarantine measures, but a significant part of these reserves will be used to cover budget deficits amid falling oil prices and a reduction in tax revenues from non-resource sector.

Table 2. Budget potential in the EAEU countries, \% of GDP, 2019 (EEC, 2020)

\begin{tabular}{|l|c|c|c|c|c|}
\hline & Armenia & Belarus & Kazakhstan & Kyrgyzstan & Russia \\
\hline $\begin{array}{l}\text { General } \\
\text { government } \\
\text { debt }\end{array}$ & 50,0 & 35,6 & 19,1 & 54,8 & 12,3 \\
\hline $\begin{array}{l}\text { General } \\
\text { government debt } \\
\text { build-up reserve }\end{array}$ & 0 & 14,4 & 30,9 & 0 & 37,7 \\
\hline Fiscal reserve & 0 & 0 & 34,3 & 0 & 7,1 \\
\hline $\begin{array}{l}\text { Potential for extra } \\
\text { expenditures }\end{array}$ & 0 & 14,4 & 65,2 & 0 & 44,8 \\
\hline
\end{tabular}

Source: Own elaboration. 
As seen from the Table 2, taking into account the limit of increasing debt to a safe level of 50\% of GDP and using the accumulated budgetary reserves, established by the Treaty on the Eurasian Economic Union, it is estimated in the Republic of Kazakhstan at $65.2 \%$ of GDP, in the Russian Federation - $44.8 \%$ Of GDP. In Belarus, the debt growth potential is $14.4 \%$ of GDP, but the depreciation of national currencies could significantly increase its level. In Armenia and Kyrgyzstan, there are no budgetary opportunities to support the economy, however, the small size of their economies provides support both from the EAEU through regional development institutions (Eurasian Development Bank (EDB), Eurasian Fund for Stabilization and Development (EFSD)) and through receiving international assistance from the International Monetary Fund.

Thus, the current conditions of turbulence and recession in the global economy and trade, caused by the COVID-19 pandemic and restrictive measures introduced by countries, a significant decrease in carbon prices, deterioration of the conditions for the entire industries and sectors' activity, a sharp decrease in global demand, significantly affect the possibilities of ensuring economic growth and stability of public finance.

\section{Conclusions and Some Policy Implications}

Taking into account the characteristics of the "new reality", according to the EEC's expert assessments, the implementation of the strategy of economic growth of the EAEU member states and further deepening of integration processes depends on the internal and external economic conditions, the level and speed of implementation of integration agreements within the EAEU and is possible under the following conditions:

- the complete elimination of restrictions on the movement of production inputs within the common EAEU markets and the development of a clear and binding plan for the development of integration cooperation with estimates of the effects for each EAEU member state;

- coordination of industrial and agro-industrial policies in the interests of building sustainable production chains within the EAEU and ensuring food security in the region, as well as timely implementation of integration agreements on the launch of common markets for goods and services, support tools for exporters from the EAEU member states to accessing and / or expanding presence in the markets of third countries;

- deepening integration in new sectors of the economy, ensuring the advanced development of the member states in new conditions: digitalization, Internet technologies, automation, education, medicine and pharmacology; launching financial levers for the development of the EAEU; 
- strengthening regionalization within the Eurasian macro-region with the SCO states, full participation of the EAEU in the Chinese initiative "One Belt, One Road"; - creating the conditions for the digitalization of foreign and mutual trade of the EAEU member states, including the following: introduction and expansion of electronic shipping documents, expansion of automatic registration and release technologies for import, export and transit of goods; automation of the zero VAT rate confirmation in mutual trade; expanding the possibility of using electronic digital signatures; promoting the use of primarily non-cash methods of payment for goods or services); - increasing the stability of the monetary and financial systems of the member states through the coordination of financial, fiscal and monetary, exchange rate policies within the EAEU, gradual transition to settlements in national currencies, development of a mechanism to reduce mutual fluctuations in exchange rates of national currencies;

- increasing the security and stability of the EAEU monetary and financial system by harmonizing legislation in the field of currency regulation and control, reducing capital outflow, expanding settlements in national currencies, reducing the use of foreign currencies in the national economies of the EAEU member states;

- formation of a sovereign system of lending for the growth of production and investment, ensuring the adjustment of the monetary system for development and expanding the possibilities of lending to enterprises in the real economy;

- increasing the financial capacity of regional development institutions (EDB and EFSD, Interstate Bank, International Investment Bank (IIB), Asian Infrastructure Investment Bank (AIIB) and intensifying their participation in the implementation of joint investment projects of the EAEU member states.

From the macroeconomic stability, sustainability of public finances and their effectiveness point of view, it is advisable to apply a whole-of-government approach to public financial management by creating interdepartmental crisis management teams in order to strengthen overall institutional capacity in the area of public financial management. Consistent measures for the entire system of government bodies in the context of the crisis and the elimination of the economic consequences of the pandemic should be:

- global cooperation in the field of eliminating the economic consequences of the coronavirus pandemic and the global economic downturn;

- modernization of policies in the field of digitalization in various forms (transformation, focusing on the implementation of digital solutions, modernization) between different blocks of the financial sector, including the banking sector, which involves the constant introduction of joint new digital technologies, innovations, products, services, operations;

- formation of the policy of national financial technologies' regulators, mainly digital, taking into account the requirements of the international regulator - the Basel Committee on Banking Supervision, the best foreign experience; 
- ensuring transparency and full disclosure of information on all budgetary measures during monitoring and regular monitoring of possible risks as new information becomes available, adequate to the conditions of a rapidly developing crisis;

- the creation of effective coordination mechanism within government bodies (between the ministries of finance and the economy, central banks) to regulate the financial sector in the face of public finance stress;

- ensuring close coordination of actions with government bodies of the subnational level in order to determine a set of measures for state support (budgetary, extrabudgetary, state guarantees, etc.);

- ensuring the continuity of funding for vital services and monitoring gains and expenditures, as well as extrabudgetary operations, while implementing a more flexible system for approving new expenditures. At the same time, it is necessary to establish clear personal responsibility for monitoring management and reporting on the measures taken.

\section{References:}

Adda, J. 2016. Economic activity and the spread of viral diseases: Evidence from high frequency data. The Quarterly Journal of Economics, 131(2), 891-941.

Baliback, E., Sayeg, A., Saxenna, S., Stone, M., Wendling K. 2020. Fiscal Risk Management Under Public Finance Stress. Available at: https://www.imf.org/ / media / Files / Publications / covid19-special-notes / Russian / ru-special-series-on-covid-19managing-fiscal-risks-under-fiscal-stress.ashx

Berger, D., Herkenhoff, K., Mongey, S. 2020. An SEIR Infectious Disease Model with Testing and Conditional Quarantine. NBER Working Paper.

EEC. 2020. Eurasian Economic Commission, analytical report "Mechanisms of response to threats to macroeconomic stability in the context of the global economic crisis caused by the pandemic". Available online:

http://www.eurasiancommission.org/ru/act/integr_i_makroec/dep_makroec_pol/eco nomyViewes/Documents/Доклад_угрозы_29.05.20_14.45.pdf.

Grima, S., Dalli Gonzi, R., Thalassinos, I.E. 2020. The Impact of COVID-19 on Malta and its Economy and Sustainable Strategies. Available at SSRN: https://ssrn.com/abstract=3644833 or http://dx.doi.org/10.2139/ssrn.3644833.

Khan, S., Rabbani, R.M., Thalassinos, I.E., Atif, M. 2020. Corona Virus Pandemic Paving Ways to Next Generation of Learning and Teaching: Futuristic Cloud Based Educational Model. Available at SSRN: https://ssrn.com/abstract=3669832.

Noja, G.G., Cristea, M. 2018. Flexicurity Measures as Key Drivers of Economic Growth Empirical Evidence for Europe. Ekonomicky Casopis, 66(7), 719-749.

Thunstrom, L., Newbold, S., Finnoff, D., Ashworth, M., Shogren, J. 2020. The Benefits and Costs of Flattening the Curve for COVID-19. SSRN working paper.

Zubarevich, N. 2020. Regional risks of a new crisis for employment and regional budgets. Monitoring of the economic situation in Russia: trends and challenges of socioeconomic development, 7(109), 3-13. 